\title{
Impact of Row \\ Spacing and Herbicide Rate and Application Method on Weed Control and Harvest Efficiency of Lima Bean
}

\author{
Sujatha Sankula, ${ }^{1}$ \\ Mark J. VanGessel, ${ }^{2}$ \\ Walter E. Kee, ${ }^{3}$ and \\ J.L. Glancey ${ }^{4}$
}

Additional IndeX WORds. cultivation, integrated weed management, Phaseolus lunatus, reduced herbicide rates

Summary. Field studies were conducted in 1997 and 1998 to evaluate labeled (1x) or reduced $(0.5 \times)$ rates of metolachlor plus imazethapyr preemergence either broadcast or band applications to lima bean (Phaseolus lunatus L.) planted in 30-inch $(76-\mathrm{cm})$ or 15 -inch $(38-\mathrm{cm})$ rows for weed control, yield, harvestability, and harvest recovery. Lima bean was planted in large plots simulating a commercial production system. All 30inch rows were cultivated once 40 days after planting in 1997 and 21 days after planting in 1998. No differences were noted in weed densities between treatments both years. Marketable lima bean yield was greater from plots that

Funding for this project was obtained through a gran from Northeast Integrated Pest Management Program. Appreciation is extended to Quintin Johnson for help in establishing and harvesting the plots and Tracy Wootten for her input and help in data collection. The cost of publishing this paper was defrayed in part by the payment of page charges. Under postal regulations, this paper therefore must be hereby marked advertisement to indicate this fact.

${ }^{1}$ Postdoctoral research associate, Department of Plant and Soil Sciences, University of Delaware, Research and Education Center, Road 6, Box 48, Georgetown, DE 19947.

${ }^{2}$ Associate professor, Department of Plant and Soil Sciences, University of Delaware, Research and Education Center, Road 6, Box 48, Georgetown, DE 19947.

${ }^{3}$ Extension vegetable specialist, Department of Plant and Soil Sciences, University of Delaware, Research and Education Center, Road 6, Box 48, Georgetown, DE 19947.

${ }^{4}$ Associate professor, Department of Bioresources Engineering, University of Delaware, Newark, DE 19717. 
were spaced 15 inches apart in 1997 only. However, total hand-harvested yield in both years, machine-harvested yield in 1998, and marketable yield in 1998 were not different between treatments. Measurements on harvest recovery revealed that a greater number of unstripped pods were left on plants after harvest in 15-inch row plots that were sprayed broadcast with $1 \times$ herbicide rate in 1997 only. Weight of beans lost per unit area and trash weight from 7-oz (200-g) bean sample was similar among treatments both years. Overall, weed control, yield, and harvest efficacy of lima bean was not impacted by row spacing, herbicide rate, or method of herbicide application in a commercial production system.

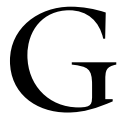
reen lima bean is a major processing crop in the midAtlantic region with 15,000 acres $(6,100$ ha) planted annually (Tarburton et al., 1995). In 1998, the latest year reported by the National Agricultural Statistics Service (U.S. Department of Agriculture, 1998), lima bean was planted on 13,000 acres $(5,300$ ha) in Delaware. Although there is considerable competition from other lima bean producing areas, those areas have limited acreage (Kee, 1986). Lima bean production in Delaware is challenging as yields on a per-acre basis are lower than other producing areas due to production issues related to soil type, pest control, harvest recovery, and harvest efficiency (Kee et al., 1997). Research on the impact of cropping practices on profitability, and implementing changes to make production more profitable will help maintain lima bean as a viable crop in Delaware.

Weed management is a primary concern to farmers for several reasons. Weeds compete with lima bean for water, nutrients, and light and can result in decreased yields. Glaze and Mullinix (1984) reported $18 \%$ yield loss with lima bean over a 3-year period with 0.25 sicklepod (Senna obtusifolia L.) plants/ $\mathrm{ft}^{2}\left(2.7\right.$ plants $\left./ \mathrm{m}^{2}\right)$.

The threshold for sicklepod is the only weed threshold established for lima bean (Glaze and Mullinix, 1984). Lima bean growers currently rely on preventive, soil-applied herbicides for weed control. Lima bean is routinely cultivated two to four times to improve weed control. Bentazon [3-(1-methyl ethyl)-(1H)-2,1,3-benzothiadiazin$4(3 \mathrm{H})$-one 2,2-dioxide] and sethoxydim \{2-[1-(ethoxyimino) butyl]-5-[2ethylthio)propyl]-3-hydroxy-2cyclohexen-1-one $\}$ are the only two postemergence (POST) herbicides labeled for lima bean. However, they control only a few broadleaf and grass weeds. Research is needed to identify alternatives or complementary methods to herbicides for lima bean that provide sufficient economic return to growers.

Reduced herbicide rates and band application of herbicides proved to be effective methods in reducing the total amount of herbicide used in the more competitive crops like corn (Zea mays L.) and soybean [Glycine max (L.) Merr.] (Buhler et al., 1992; DeFelice et al., 1989; Mulder and Doll, 1993). Cultivation used in combination with reduced herbicide rates or banded applications has improved total weed control in soybean and corn (Buhler et al., 1992; DeFelice et al., 1989; Gunsolus, 1990; Mulder and Doll, 1993). Yet, limited research has been conducted in less competitive crops such as lima bean. Reduced herbicide rates may be successful in less competitive crops when used in combination with other methods such as cultivation. Preemergence (PRE) herbicides may not provide season-long weed control and may require a POST application or a cultivation for additional weed control (Peters et al., 1965; Shaw et al., 1989; Wax et al., 1977).

Decreasing space between crop rows has been discussed as a strategy to reduce the need for herbicides (Patriquin, 1988; Teasdale and Frank, 1983). Narrow row crops may require less herbicide than wide row crops for equally effective weed control (Forcella et al., 1992). Crops grown in narrow rows [ 15 inches $(38 \mathrm{~cm})$ or less] shade weed seedlings more than those grown in traditional wide rows [30 inches (76 $\mathrm{cm}$ )] (Yelverton and Coble, 1991). Increasing seeding rate as row spacings decrease has not improved lima bean yields in the mid-Atlantic region (Sirait et al., 1994; Wootten, 1994).

Weedy fields reduce raw product recovery by harvesters and generate more trash in the harvested product. Research by Kee et al., (1997) revealed that trash content in harvested lima bean averaged $13 \%$ in a 2 -year test period. Weeds reduce harvest efficiency and add costs during raw product preparation at the processing plant (Glancey et al., 1995). Weeds like horsenettle (Solanum carolinense L.), eastern black nightshade
(Solanum ptycanthum Dun.), and morningglory (Ipomea L.) produce berries or seeds similar in size or color to lima bean. The presence of these weed seeds, as well as other foreign materials, can result in a penalty or price reduction to the grower including outright seed rejection by the processor (Kee at al., 1997). Removing weed seeds and plant parts with the cleaning systems on the combines or with color sorters in the processing plant is difficult. At present, the best method to reduce weed seed contamination from the harvested product is an effective weed control program during the growing season (Glancey et al., 1997).

Poor harvest recovery represents a significant economic loss to lima bean growers and processors. On an average, $>15 \%$ of the lima bean crop is left in the field after harvest with pod-stripper combines. More than $75 \%$ of the harvest loss occurs at the head of the combine where the pods are stripped from the plant. Losses during threshing and cleaning averaged $<25 \%$ of the total harvest loss (Glancey et al., 1997). Three factors that effect lima bean recovery at the combine head are field levelness, relationship between combine ground speed and picking reel speed, and lima bean cultivar (Kee et al., 1997).

Kee and Glancey (1996) reported that lima bean cultivars with small plant type like 'Maffei-15' exhibited twice the head loss compared with cultivars having larger biomass. The higher head loss with smaller cultivars was attributed to the fundamental plant architecture in which a greater portion of the pod set is close to the ground. Previous research by Sirait et al. (1994) reported differences in pod set of the same lima bean cultivar planted under different row spacings. When planted in 15-inch rows, pods grew lower on the plant than in 30 -inch rows, a response to high plant population density also observed in soybean (Hanway and Thompson, 1967). Conversely, growth habit of 'Maffei15' lima bean was more upright with few pods set close to the ground in 15inch rows than 30-inch rows (S. Sankula, M.J. VanGessel, K.L. Everts, and W.E. Kee, unpublished data).

Early research on lima bean evaluated the effect of a single independent variable on harvest and harvest recovery (Kee and Glancey, 1996). This study was initiated with a multifactor approach to evaluate the impact of different row spacings with labeled or reduced herbi- 
Table 1. Preharvest weed counts in lima bean as influenced by row spacing, herbicide rate, and method of application in 1997 and $1998 .^{\mathrm{z}}$

\begin{tabular}{|c|c|c|c|}
\hline \multirow{2}{*}{$\begin{array}{l}\text { Row spacing } \\
\text { [inches }(\mathrm{cm})]\end{array}$} & \multirow[b]{2}{*}{ Treatment $^{\mathbf{y}}$} & \multicolumn{2}{|c|}{ Weeds/ft ${ }^{2 x}$} \\
\hline & & 1997 & 1998 \\
\hline $30(76)$ & $1 \times$ broadcast & 3 & 0 \\
\hline $15(38)$ & $1 \times$ broadcast & 2 & 0.1 \\
\hline $30(76)$ & $0.5 \times$ broadcast & 1 & 0 \\
\hline $15(38)$ & $0.5 \times$ broadcast & 3 & 0 \\
\hline $30(76)$ & $1 \times$ band & 3 & 0.1 \\
\hline $30(76)$ & $0.5 \times$ band & 1 & 0.1 \\
\hline $\operatorname{LSD}_{(0.05)}$ & & NS & NS \\
\hline
\end{tabular}

${ }^{2}$ Weed density is total of broadleaf and grass weeds present on 17 Sept. 1997 and 28 Sept. 1998.

y Herbicide applications comprised of $1 \times$ or $0.5 \times$ rates of metolachlor plus imazethapyr preemergence. The $1 \times$ rate applied broadcast spray or in a 10 -inch $(25-\mathrm{cm})$ band was $1.34 \mathrm{lb} /$ acre $\left(1.5 \mathrm{~kg} \cdot \mathrm{ha}^{-1}\right)$ metolachlor plus $0.045 \mathrm{lb} /$ acre $\left(0.05 \mathrm{~kg} \cdot \mathrm{ha}^{-1}\right)$ imazethapyr. Only 30 -inch spaced rows were cultivated once, both years.

${ }^{\mathrm{x}} 1$ weed $/ \mathrm{ft}^{2}=11$ weeds $/ \mathrm{m}^{2}$.

cide rates, applied broadcast or banded on weed control, yield, and harvest efficiency of lima bean.

\section{Materials and methods}

Field experiments were conducted at University of Delaware's Warrington Farm located near Harbeson, Del., in 1997 and on a grower's farm near Dover, Del., in 1998. Soil was Downer loamy sand (coarse-loamy, siliceous, mesic, Typic Hapludults) in 1997 and Sassafras sandy loam (fine-loamy, siliceous, mesic, Typic Hapludults) in 1998. Soil pH was 5.4 in 1997 and 5.3 in 1998 with $1.2 \%$ and $1.4 \%$ organic matter, respectively.

'Maffei 15' lima bean was seeded on 27 July, 1997 and 13 July, 1998. Seeding depth was 1 to 1.2 inches $(2.5$ to $3 \mathrm{~cm}$ ), and row spacings were 15 and 30 inches. Lima bean was planted in large plots to simulate a commercial production. Plot size was $30 \times 689 \mathrm{ft}(9$ $\times 210 \mathrm{~m})$ in 1997 and $30 \times 886 \mathrm{ft}(9 \times$ $270 \mathrm{~m}$ ) in 1998. Plots with 15 -inch rows consisted of 14 planted rows while 30 -inch rows had eight planted rows. Total plant population with 30 -inch row spacings was 71,0000 plants/acre $(175,000$ plants/ha) and 142,000 plants/acre (350,000 plants/ha) in 15inch rows.

Metolachlor [2-chloro-N-(2-ethyl6-methylphenyl)-N-(2-methoxy-1methylethyl) acetamide] plus imazethapyr $\{2$-[4,5-dihydro-4-methyl4-(1-methylethyl)-5-oxo-1H-imidazol2-yl]-5-ethyl-3-pyridinecarboxylic acid\} was applied either broadcast or as a band at $1 \times$ and $0.5 \times$ rates PRE [ 1.34 and $0.045 \mathrm{lb} /$ acre $\left(1.5\right.$ and $\left.0.05 \mathrm{~kg} \cdot \mathrm{ha}^{-1}\right)$ of active ingredient, respectively, for the $\mathrm{l} \times]$ within $\mathrm{l} \mathrm{d}$ of planting. This is the most common herbicide combination used for lima bean production in the
mid-Atlantic region. The 15 -inchspaced lima bean was sprayed only broadcast with the herbicide mixture while 30 -inch rows received either a broadcast or band application. Band width was 10 inches $(25 \mathrm{~cm})$ centered over the crop row. Lima bean was irrigated with solid set sprinklers as needed to maintain adequate soil moisture for growth. All the 30-inch-spaced rows were cultivated once both years ( $40 \mathrm{~d}$ after planting in 1997 and $21 \mathrm{~d}$ after planting in 1998). The delay in cultivation in 1997 was due to prolonged wet weather. Weedy check plots were not included in the study as it was not feasible due to large plot size.

Weed counts were made at five randomly chosen areas using a quadrat of $2.8 \mathrm{ft}^{2}\left(0.25 \mathrm{~m}^{2}\right)$ before lima bean harvest. The quadrat was laid perpendicular to the lima bean rows and all the weeds within the quadrats were counted.

At harvest, a 39-ft (12-m) long area (from three random locations) from each of the center two 30 -inch rows and four 15-inch rows was hand harvested for the final yield. Pods were mechanically threshed and bean weight per plot recorded. In addition, a $21-\mathrm{oz}(600-\mathrm{g})$ threshed bean sample was passed through a sieve with 0.37 -inch (9.4$\mathrm{mm}$ ) diameter holes, and weight of beans that were retained and those that fell through the sieve were recorded separately. Weight of plump beans that stayed on the sieve is a measure of marketable beans. Percent marketable beans [ (weight of beans retained on sieve $/ 21 \mathrm{oz}) \times 100]$ and percent marketable yield [(yield/100 $) \times$ percent marketable beans] were calculated based on weight of plump beans that were retained on the sieve.

Additionally, entire plots were harvested by a commercial combine and yields were recorded. In 1998, only two replications were machine harvested for final yield due to inclement weather. However, all four replications were hand harvested for yield in 1998. As a measure of harvest recovery, number of pods left on plants by pod stripper and weight of beans left on ground in $66-\mathrm{ft}^{2}$ $\left(6-\mathrm{m}^{2}\right)$ area at three locations were determined. Trash from a $7-\mathrm{oz}(200-\mathrm{g})$ bean sample was separated, weight recorded, and percent trash determined.

Carpetweed (Mollugo verticillata L.), ivy morningglory [ Ipomea hederacea (L.) Jacq.], common purslane (Portulaca oleracea L.), and fall panicum (Panicum dichotomiflorum Michx.) were the dominant weeds in 1997 whereas goosegrass (Eleusine indica L.), fall panicum, and lambsquarters (Chenopodium album L.) were dominant weeds in 1998.

At both locations, experimental design was a randomized complete block. There were four replications in 1997 and three replications in 1998. All data were subjected to analysis of variance and treatment means were separated by LSD at the $P=0.05$.

\section{Results and discussion}

Due to significant year $\times$ treatment interactions, all data are presented by years.

Weed density. Weed numbers were greater in 1997 compared to 1998 (Table 1). However, no differences were noted in weed counts between treatments regardless of row spacing, herbicide rate, or application method both years.

LIMA BEAN YieLd (HAND haRVEST). Except for marketable yield in 1997, treatments did not differ in yield related measurements such as total yield and percent marketable beans (Table 2). Marketable yield was highest from rows that were 15 inches $(38 \mathrm{~cm})$ apart regardless of herbicide rate and was different from the rest of the treatments in 1997 only. Marketable yield was improved by $28 \%$ in 15 -inch rows with either herbicide rates compared to 30 inch $(76-\mathrm{cm})$ rows.

Lima bean yield from machine harvest was lower than the yield from hand harvest in both years (Table 3 ). Reduction can be attributed to harvest losses associated with machine harvest. Though there was no significant difference, increase in total yield from handharvested 15-inch rows compared to 30 -inch rows was more pronounced 
Table 2. Hand-harvested lima bean yield and marketable yield as influenced by weed control treatments in 1997 and 1998.

\begin{tabular}{|c|c|c|c|c|c|c|c|}
\hline \multirow[b]{2}{*}{$\begin{array}{l}\text { Row } \\
\text { spacing } \\
\text { [inches (cm)] }\end{array}$} & \multirow[b]{2}{*}{ Treatment $^{\mathrm{z}}$} & \multicolumn{3}{|c|}{1997} & \multicolumn{3}{|c|}{1998} \\
\hline & & $\begin{array}{c}\text { Total } \\
\text { yield } \\
\left.\text { (lb/acre }^{w}\right)\end{array}$ & $\begin{array}{c}\text { Marketable } \\
\text { beans }^{\mathrm{y}} \\
(\%) \\
\end{array}$ & $\begin{array}{c}\text { Marketable } \\
\text { yield } \\
\text { (lb/acre) }\end{array}$ & $\begin{array}{c}\text { Total } \\
\text { yield } \\
\text { (lb/acre) } \\
\end{array}$ & $\begin{array}{c}\text { Marketable } \\
\text { beans } \\
(\%) \\
\end{array}$ & $\begin{array}{c}\text { Marketable } \\
\text { yield } \\
\text { (1b/acre) } \\
\end{array}$ \\
\hline $30(76)$ & $1 \times$ broadcast & 2384 & 62 & 1478 & 3222 & 67 & 2158 \\
\hline $15(38)$ & $1 \times$ broadcast & 3059 & 67 & 2049 & 4074 & 74 & 3015 \\
\hline $30(76)$ & $0.5 \times$ broadcast & 2300 & 62 & 1426 & 3694 & 68 & 2512 \\
\hline $30(76)$ & $0.5 \times$ band & 2425 & 63 & 1528 & 3088 & 64 & 1976 \\
\hline $\operatorname{LSD}_{(0.05)}$ & & NS & NS & 466 & NS & NS & NS \\
\hline
\end{tabular}

${ }^{\mathrm{z}}$ Herbicide applications comprised of $1 \times$ or $0.5 \times$ rates of metolachlor plus imazethapyr preemergence. The $1 \times$ rate applied broadcast spray or in a 10 -inch $(25$-cm $)$ band was $1.34 \mathrm{lb} /$ acre $\left(1.5 \mathrm{~kg} \cdot \mathrm{ha}^{-1}\right)$ metolachlor plus $0.045 \mathrm{lb} /$ acre $\left(0.05 \mathrm{~kg} \cdot \mathrm{ha}^{-1}\right)$ imazethapyr. Only 30 -inch-spaced rows were cultivated once, both years.

${ }^{y}$ A $21-\mathrm{oz}(600-\mathrm{g})$ threshed bean sample was passed through a sieve with 0.37 -inch $(9.4-\mathrm{mm})$ diameter holes, and weight of beans that were retained and those that fell through the sieve were recorded separately. Percent marketable beans were calculated by using the formula, (weight of beans retained on the sieve $/ 21$-oz) $\times 100$.

${ }^{\mathrm{x}}$ Marketable yield $=$ total yield $\times$ percent marketable beans.

${ }^{\mathrm{w}} \mathrm{l} \mathrm{lb} / \mathrm{acre}=1.12 \mathrm{~kg} \cdot \mathrm{ha}^{-1}$

Table 3. Machine-harvested lima bean yield as influenced by row spacing, herbicide rate, and method of application in 1997 and 1998.

\begin{tabular}{|c|c|c|c|}
\hline \multirow{3}{*}{$\begin{array}{l}\text { Row } \\
\text { spacing } \\
\text { [inches (cm)] }\end{array}$} & \multirow[b]{3}{*}{ Treatment $^{\mathrm{z}}$} & \multicolumn{2}{|c|}{ Lima bean yield } \\
\hline & & 1997 & 1998 \\
\hline & & lb/acre ${ }^{y}$ & lb/acre \\
\hline $30(76)$ & $1 \times$ broadcast & 1867 & 2214 \\
\hline $15(38)$ & $\mathrm{I} \times$ broadcast & 1815 & 2304 \\
\hline $30(76)$ & $0.5 \times$ broadcast & 1710 & 2365 \\
\hline $15(38)$ & $0.5 \times$ broadcast & 1991 & 2320 \\
\hline $30(76)$ & $1 \times$ band & 1621 & 2481 \\
\hline $30(76)$ & $0.5 \times$ band & 2291 & 2190 \\
\hline $\operatorname{LSD}_{(0.05)}$ & & 529 & NS \\
\hline
\end{tabular}

${ }^{\mathrm{z}}$ Herbicide applications comprised of $1 \times$ or $0.5 \times$ rates of metolachlor plus imazethapyr preemergence. The $1 \times$ rate applied broadcast spray or in a 10 -inch $(25-\mathrm{cm})$ band was $1.34 \mathrm{lb} /$ acre $\left(1.5 \mathrm{~kg} \cdot \mathrm{ha}^{-1}\right)$ metolachlor plus $0.045 \mathrm{lb} /$ acre $\left(0.05 \mathrm{~kg} \cdot \mathrm{ha}^{-1}\right)$ imazethapyr. Only 30 -inch-spaced rows were cultivated once, both years.

${ }^{\mathrm{y}} \mathrm{l} \mathrm{lb} / \mathrm{acre}=1.12 \mathrm{~kg} \cdot \mathrm{ha}^{-1}$. than yield from machine harvest in both years. This may have been due to higher yield losses in 15-inch rows compared to 30-inch rows with machine-harvest. Except for yield from 30 -inch rows where $0.5 \times$ rate of herbicides were banded in 1997, no differences were recorded in yield between any of the treatments both years. The reason for the increase in yield in 1997 when $0.5 \times$ rate of herbicides were banded in 15inch rows was not clear.

Harvest recovery evaluations. Number of pods left on lima bean plants after harvest and trash weight in the harvested samples were similar for all treatments both years (Table 4). Weight of beans lost per unit area was greater when $1 \times$ herbicide rate was applied

Table 4. Harvest efficiency ${ }^{\mathrm{Z}}$ of lima bean as affected by row spacing, herbicide rate, and method of herbicide application in 1997 and 1998.

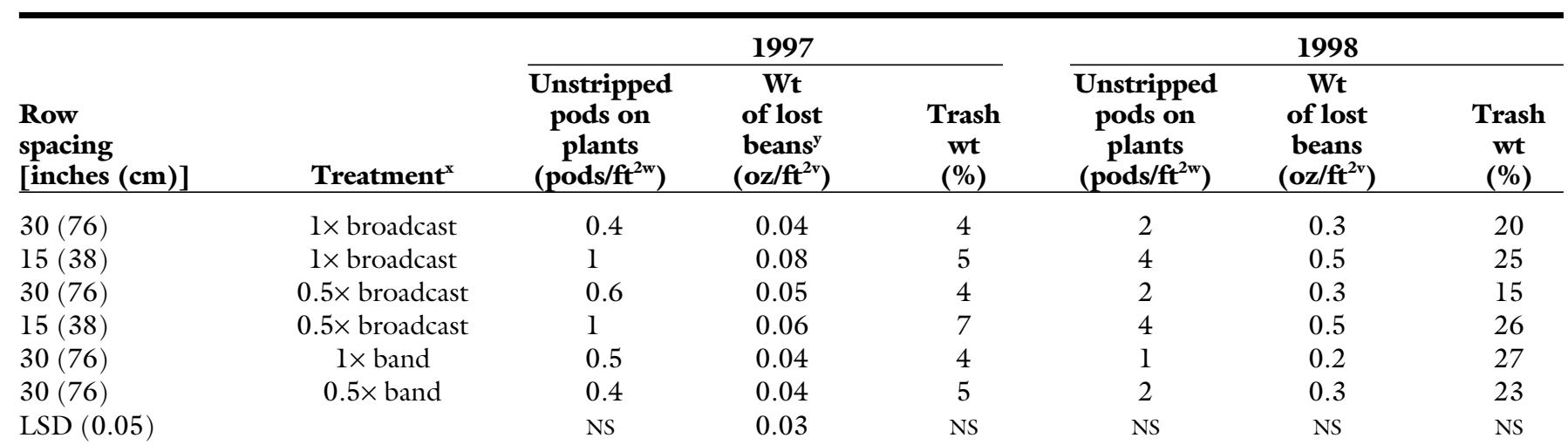

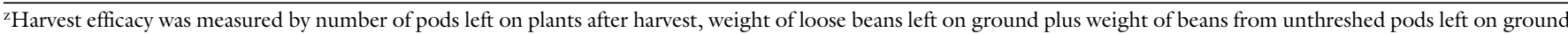
after lima bean harvest, and weight of trash from $7-\mathrm{oz}(200-\mathrm{g})$ of bean sample expressed in \%. Trash weight was higher in 1998 is due to inclusion of unmarketable beans in the trash.

yeight of beans lost $=$ weight of loose beans left on ground plus weight of beans from unthreshed pods left on ground after lima bean harvest.

${ }^{x}$ Herbicide applications comprised of $1 \times$ or $0.5 \times$ rates of metolachlor plus imazethapyr preemergence. The $1 \times$ rate applied broadcast spray or in a 10 -inch $(25$-cm $)$ band was $1.34 \mathrm{lb} /$ acre $\left(1.5 \mathrm{~kg} \cdot \mathrm{ha}^{-1}\right)$ metolachlor plus $0.045 \mathrm{lb} /$ acre $\left(0.05 \mathrm{~kg} \cdot \mathrm{ha}^{-1}\right)$ imazethapyr. Only 30 -inch-spaced rows were cultivated once, both years.

${ }^{\mathrm{w}} 1 \mathrm{pod} / \mathrm{ft}^{2}=11$ pods $/ \mathrm{m}^{2}$.

${ }^{\mathrm{v}} \mathrm{l} \mathrm{oz} / \mathrm{ft}^{2}=305 \mathrm{~g} \cdot \mathrm{m}^{-2}$. 
broadcast on 15-inch row plots in 1997 , the reason for which is not apparent. However, no differences were observed between treatments in 1998 .

Results from these studies indicate that reduced rates of metolachlor plus imazethapyr as either broadcast or band applications (PRE) resulted in weed control, lima bean yields, and harvest recovery equivalent to full rates regardless of row spacings. Our findings are in agreement with similar soybean research that reported no differences in weed control and yield between full and reduced rates of herbicides and narrow [10-inch $(25-\mathrm{cm})$ and 15 -inch rows] and wide (30-inch) row spacings (Forcella et al., 1992; Muyonga et al., 1996).

The inconsistency of the effect of row spacing on economic (marketable) yield as noted in this study is similar to the results reported by Larson and Peng Fi-Li (1948). Larson and Peng Fi-Li (1948) showed that depending on location in Pennsylvania, lima bean in 20inch $(5 \mathrm{l}-\mathrm{cm})$ rows produced more, the same, or less economic yield compared to 30 -inch rows. Sirait et al. (1994) suggested that higher economic yield in 15 -inch rows which had high plant populations compared to 30 -inch rows was associated with greater plant weights per plot. In this study, insignificant yield increase noted in 15-inch rows may have been due to higher plant population with 15-inch rows compared to 30inch rows.

Though not significant, harvest losses were higher in 15 -inch rows than in 30-inch rows in both years. For instance, weight of beans lost on ground were $44 \%$ to $67 \%$ higher in 15 -inch rows than that recorded in 30 -inch rows in 1998. This translates to a bean loss of 370 to $507 \mathrm{lb} /$ acre ( 415 to 568 $\mathrm{kg} \cdot \mathrm{ha}^{-1}$ ) worth $\$ 358$ to $\$ 492 /$ acre ( $\$ 145$ to $\$ 199 / \mathrm{ha})$. This is a substantial yield and monetary loss to the grower.

Reduced herbicide rates provided consistent weed control similar to the $1 \times$ rate in this study without a cultivation in 15-inch rows. However, some weeds escape, even at full rates of herbicides, requiring a follow up cultivation. It appears that there is no clear benefit to planting lima bean in narrow rows. In addition to no yield advantage, harvest losses as discussed above are higher with 15-inch rows compared to 30-inch rows.
Also, conventional harvester configuration and setup may not be well suited to harvest lima bean grown in narrow rows. Future research should identify if potential other benefits exist before advocating narrow row spacing in lima bean.

Based on the results of this research, planting lima bean in traditional wide rows and switching from chemical-intensive systems to low-use rate systems complemented with mechanical weed management appears to be a viable alternative. The use of reduced herbicide rates can fit with intensivemanagement, integrated-production systems. This information helps in developing tactics for integrated weed management systems in lima bean.

\section{Literature cited}

Buhler, D.D., J.L. Gunsolus, and D.F. Ralston. 1992. Integrated weed management techniques to reduce herbicide inputs in soybeans. Agron. J. 84:973-978.

DeFelice, M.S., W.B. Brown, R.J. Aldrich, B.D. Sims, D.T. Judy, and D.R. Guethle. 1989. Weed control in soybeans (Glycine $\max$ ) with reduced rates of postemergence herbicides. Weed Sci. 37:365-374.

Forcella, F., M.E. West Gate, and D.D. Warnes. 1992. Effect of row width on herbicide and cultivation requirements in row crops. Amer. J. Alt. Agr. 7:161-167.

Glancey, J.L., W.E. Kee, T.L. Wootten, and B.C. Postles. 1995. Harvesting of green peas and lima beans for processing. Proc. Amer. Soc. Agr. Eng. Annu. Mtg. 95:1773.

Glancey, J.L., W.E. Kee, and T.L. Wootten. 1997. Machine harvest of lima beans for processing. J. Veg. Prod. 3:59-68

Glaze, N.C. and B.G. Mullinix, Jr. 1984. Competitive effects of sicklepod on lima beans. Weed Sci. 32:1-3.

Gunsolus, J.L. 1990. Mechanical and cultural weed control in corn and soybeans. Amer. J. Alt. Agr. 5:114-119.

Hanway, J.J. and H.E. Thompson. 1967. How a soybean plant develops. Spec. Rep. 53. Iowa State Univ. Coop. Extn. Serv., Ames.

Kee, Jr., W.E. 1986. Lima beans show steady success in Delaware. Amer. Veg. Grower 34:78-79.

Kee, W.E. and J.L. Glancey. 1996. Rating the pod setting habit of lima bean cultivars to improve harvest recovery with the pod stripper combine. HortScience 31:669 (abstr.).
Kee, Jr. W.E., J.L. Glancey, and T.L. Wootten. 1997. The lima bean: A vegetable crop for processing. HortTechnology 7:119-128.

Larson, R.E. and L. Peng Fi-Li. 1948. The influence of various row and plant spacings on yield of lima beans. Proc. Amer. Soc. Hort. Sci. 51:479-485.

Mulder, T.A. and J.D. Doll. 1993. Integrating reduced herbicide use with mechanical weeding in corn (Zea mays). Weed Technol. 7:226-232.

Muyonga, K.C., M.S. DeFelice, and B.D. Sims. 1996. Weed control with reduced rates of four soil-applied soybean herbicides. Weed Sci. 44:148-155.

Patriquin, D.G. 1988. Weed control in organic farming systems, p. 303-317. In: M.A. Altieri and M. Liebman (eds.). Weed management in agro-ecosystems: Ecological approaches. CRC Press, Boca Raton, Fla.

Peters, E.J., M.R. Gebhardt, and J.F. Stritzke. 1965. Interrelations of row spacings, cultivations, and herbicides for weed control in soybeans. Weeds 13:285-289.

Shaw, D.R., C.A. Smith, and C.E. Snipes. 1989. Sicklepod (Cassia obtusifolia) control in soybean (Glycine max) grown in rotations of $97-$ and $18-\mathrm{cm}$ row spacings. Weed Sci. 37:748-752.

Sirait, Y., W.G. Pill, and W.E. Kee, Jr. 1994. Lima bean (Phaseolus lunatus L.) response to irrigation regime and plant population density. HortScience 29:7173.

Tarburton, J.F., T.W. Feurer, and D.M. Bay. 1995. Delaware agricultural statistics summary for 1994. Del. Dept. Agr.

Teasdale, J.R. and J.R. Frank. 1983. Effect of row spacing on weed competition with snap beans (Phaseolus vulgaris). Weed Sci. 31:81-85.

U.S. Department of Agriculture. 1998. Lima bean for processing: acreage, yield, value, and production, 1970-98. Natl. Agr. Stat. Summary, Washington, D.C. p. 10-12.

Wax, L.M., W.R. Nave, and R.L. Cooper. 1977. Weed control in narrow and wide row soybeans. Weed Sci. 25:73-78.

Wootten, T.L. 1994. The effects of heat stress on retention and abscission of lima bean reproductive structures. MS diss. Univ. Del., Newark.

Yelverton, F.H. and H.D. Coble. 1991. Narrow row spacing and canopy formation reduces weed resurgence in soybeans ( Glycine max). Weed Technol. 5:169-174. 